\title{
A CDA Approach to the Biased Interpretation and Representation of Ideologically Conflicting Ideas in Western Printed Media
}

\author{
Amir Shojaei \\ Department of English, Quchan Branch, Islamic Azad University, Quchan, Iran \\ Kazem Youssefi \\ Department of English, Quchan Branch, Islamic Azad University, Quchan, Iran \\ Hossein Shams Hosseini \\ Department of English, Quchan Branch, Islamic Azad University, Quchan, Iran
}

\begin{abstract}
As one of the most important sites in which and through which national agenda is articulated and disseminated, national newspapers play particularly important roles in representing and interpreting news stories (Li, 2009, p. 85). Drawing on Van Dijk's (1998) socio-cognitive approach and Fairclough's (1995) approach of intertextual analysis of news discourse and within the paradigm of Critical Discourse Analysis (CDA), this study examined how three cases of ideologically conflicting ideas are interpreted and represented in western printed media. The conflicting ideas taken into account included Iran Nuclear Program, Iran Sanctions, and Syria Crisis for which the ideological stances of Iranian officials and most of the western countries strongly differ. Meanwhile, the study attempted to clarify how linguistic tools can carry ideological traits in their discoursal properties resulting in misrepresentation of above-mentioned news stories while at the same time legitimating the ideological stances of their favorite sources. Interestingly, the findings revealed that linguistic tools are among the most important devices through which ideological proclivities can be placed in the news stories of newspapers. Besides, such linguistic tools as lexicalization and collocational patterns, presupposition, intertextuality, and modality were identified as the items with the highest frequency of use in the representations of such news stories.
\end{abstract}

Index Terms - critical discourse analysis, ideology, bias, representation, conflicting ideas, western printed media

\section{INTRODUCTION}

As Das (2009) puts, with the rapid advancement of science and technology in the $21^{\text {st }}$ century the role of media is omnipresent for all "positive and negative changes" in the society no matter of geographical location but it depends how media functions in its duties and responsibilities in such situation. Hence, media as a whole has its "potentiality either to affect any social development or to get affected by the factors of the social change" (Das, 2009, p. 1). Television broadcasts and newspaper stories are arguably the most important source of information about the conduct of governments and politicians. The media's central role in determining what information the public has justifies the recent increased attention to how the media shapes public knowledge, attitudes, and behavior (Karlan \& Bergan, 2007, p. 2). Media sources may influence the public not only by choosing the slant of a particular report, but also merely by choosing what to report (George \& Waldfogel, 2006, as cited in Gerber, Karlan \& Bergan, 2007, p. 2).

The news media, however, is widely viewed as biased. But the question is that: where can the bias in reporting be detected and what is the tool for it? Answering to this question, Richardson (2007) introduces "Language as the medium to do so" (pp. 13-14). He examines the language use [discourse] of newspapers and identifies language as a "non-neutral element":

[...] language is social. Language is central to human activity; indeed it is one of the things that make us human. It is through the use of language that we grant meaning to our actions; equally, it is through our use of language that we can attempt to remove meaning from our actions. (Richardson, 2007, p. 10)

Given all the above-mentioned ideas, this study tries to investigate the ways language is used by the public media in general and online printed news media in particular to represent and interpret some news stories of conflicting ideas between Iran and western countries. Among the existing conflicting ideas between Iran and the majority of western countries, three issues which are more arguable and transparent have been chosen including: Iran's Nuclear Program, Iran Sanctions, and Syria Crisis which are still some ongoing issues at present. Furthermore, it was attempted to show how "the use of language" can change the meanings of ideas as well as reversing them in some strong cases. 


\section{LITERATURE REVIEW}

\section{A. Language}

Language is an important aspect of "personal and cultural identity, as well as being the carrier of knowledge" (Askeland \& Payne, 2006, p. 736). Rogers and colleagues (2005) believe that language indexes, expresses, and constitutes social relations, while and at the same time challenging social relations. In this framework, language becomes "dialogic, intertextual, and historically based" (p. 376). Considering social and cultural aspects of language Bell (1997) mentions that "language constitutes social reality as well as reflecting it" (Wang, 2009, p. 753). Moreover, Bakhtin (1981) believes that there is no creation of language in the discourse that is not influenced by certain social groups, classes, discourses, conditions or relationships; we thus consider language to be "both constitutive of the social world as well as constituted by other social practices" (as cited in Wang, 2009, p. 753; Li, 2009, p. 91; Joye, 2010, p. 590). Investigating the relationship between media and language choice is of prime importance in critical and analytical studies and that is the reason why Popp (2006) expresses that "media language choice is an institutionalized means of framing reality" (p. 6). Therefore, framing social, political, cultural, economic, and ideological realities highly depends on the language use of the mass media in general, and printed news media in particular. In this case Ives (2004) narrates Gramsci's notion of language where he saw language as central to establishing, and to understanding the organization of consent. According to Ives (2004, p. 7):

Language is spread predominantly not by government or state coercion [or persuasion], military or police action, but by speakers accepting the prestige and utility of new languages, phrases or terms. Yet the idea that we have totally free choice over the language we use, the words we speak, is clearly misleading. (Ives, 2004, p. 7, as cited in DemontHeinrich, 2008, p. 274)

\section{B. Ideology}

The concept of ideology has been defined by many different schools of thought and a vast number of different scholars working on ideology, power relations, hegemonic trends as well as discourse studies. Once it was largely associated with the "Marxist theory of base and superstructure" (Vighi \& Feldner, 2007, p. 144). Bloor and Bloor (2007) believe that "we can gloss ideology as a set of beliefs or attitude shared by members of a particular social group" (p. 10) They truly mention that most discourse used by members of a group tends to be ideologically based. However, the beliefs or attitudes that stem from ideology may not always be held consciously by individuals; they can be so deeply ingrained in our thought patterns and language that we take them for granted as self-evident. Where a belief is held consciously, it is possible to consciously question what it means or even to stand out against it as an individual. However, where it has become a socially imbued unconscious attitude, it is much more difficult to question - even to oneself - and extremely hard to challenge openly in the social arena (Bloor \& Bloor, 2007, p. 10).

While numerous theoretical definitions of ideology exist, it is believed that Van Dijk's (1998) definition is particularly well suited to the study of ideology through a critical discourse analysis approach which is the framework of this research task. To elaborate the case let's define the concept of ideology in Van Dijk's theoretical framework where it refers to the social representations within a group, embodying between-group conflicts. In his terms:

Ideologies are representations of who we are, what we stand for, what our values are, and what our relationships are with other groups, in particular our enemies or opponents, that is, those who oppose what we stand for, threaten our interests and prevent us from equal access to social resources and human rights (residence, citizenship, employment, housing, status and respect, and so on). In other words, an ideology is a self-serving schema for the representation of $U s$ and Them as social groups. This means that ideologies probably have the format of a group schema, or at least the format of a group schema that reflects Our fundamental social, economic, political or cultural interests. (Van Dijk, 1998, p. 69, as cited in Tardy, 2009, p. 267)

\section{Van Dijk's Notion of 'Ideological Square'}

Elaborating on his thesis, Van Dijk (1998) contributes a useful theoretical concept he calls the 'ideological square', which encapsulates the twin strategies of positive 'ingroup' description and negative 'outgroup' description. The double strategy of this binary opposition is often manifested in discourse by lexical choice and other linguistic features (Van Dijk, 1998, p. 33, as cited in Hakam, 2009, p. 37). Van Dijk maintains that many group ideologies involve the representation of Self and Others, Us and Them. Many therefore seem to be polarized - We are Good and They are Bad, and the 'ideological square' functions to polarize in- and out-groups in order to present the 'We' group in a favorable light and the 'They' group unfavorably (Kuo \& Nakamura, 2005, p. 410). Thus, as Van Dijk (1993) clarifies an additional strategy used to express assimilationism is to represent the 'other' in a negative light which is known as 'negative other presentation' (Tardy, 2009, p. 282). This ideological polarization may be implemented by a large variety of forms such as the choice of lexical items that imply positive or negative evaluations, as well as in the structure of whole propositions and their categories (as in active/passive, etc.). This strategy of polarization consists of "emphasizing our good properties/actions; emphasizing their bad properties/actions, mitigating our bad properties/actions; and mitigating their good properties/actions" (Kuo \& Nakamura, 2005, p. 410).

\section{Critical Discourse Analysis}


There are a number of approaches towards CDA. Amongst such various approaches to CDA this study mainly considers the frameworks presented by Van Dijk (1996, 2001), and Fairclough (1999) where Van Dijk articulates Textual Linguistics and Social Cognition; and Fairclough has a more Sociological approach (Resende, 2009, p. 364). According to Fowler (1991), believing that language is a reality-creating social practice, and anything that is said or written about the world is articulated from a particular ideological position, CDA emphasizes the need to critically examine the role of newspaper language. The ideology of the news writers, according to CDA, is not always apparent but is hidden in the subtle choice of linguistic forms, and only by examining linguistic structures in a 'critical' way can the ideological underpinnings of news discourse be unpacked (Fowler, 1991, p. 10, as cited in Kuo \& Nakamura, 2005, p. 395). In this regard, $\mathrm{Ng}$ and Bradac (1993) echo CDA by emphasizing the importance of not accepting a presented reality at its face value but reading it critically instead (Kuo \& Nakamura, 2005, pp. 410-11). CDA therefore provides the means to investigate the ways in which language operates in social life. It illuminates the universalization of specific discourses and the linking of specific texts to ideologies, perceived as symbolic constructions working towards maintaining dominant structures (Thompson, 1990, as cited in Resende, 2009, p. 365).

\section{E. Van Dijk's Socio-cognitive Approach to CDA}

In Van Dijk's (2001) model of critical discourse analysis, three components illustrate how discourse may reflect social ideologies, namely: discourse, cognition, and society. Discourse refers to discourse structures realized in diverse forms, such as written text, speech, gestures, facial expressions, etc. Cognition here includes personal/social beliefs, understanding, and evaluation engaged in discourse, while society concerns local interlocutor relationships or global societal structures such as political systems and group/subgroup relations. Concerned with all three aspects at once, Van Dijk states that 'it is only the integration of these accounts that may reach descriptive, explanatory and especially critical adequacy in the study of social problems' (p. 98). In other words, social ideology may be reflected by identifying 'the crucial link between macrolevel analyses of groups, social formations and social structure, and microlevel studies of situated, individual interaction and discourse' (Van Dijk, 1995, p. 1, as cited in Wang, 2009, p. 748).

\section{F. Fairclough's Approach to CDA}

Like van Dijk's, Fairclough's (1995) framework for discourse analysis has three components. The first dimension is text analysis, which includes both micro- and macro-levels of text structures; Fairclough's analysis at the textual level involves use of Halliday's systemic functional linguistics and the three domains of ideational, interpersonal, and textual analysis (Kuo \& Nakamura, 2005). The ideational functions include meta-narratives that circulate in society. Analysis at this level includes transitivity, which involves the different processes, or types of verbs, involved in the interaction. The interpersonal functions are the meanings of the social relations established between participants in the interaction. Analysis of this domain includes an analysis of the mood (whether a sentence is a statement, question, or declaration) and modality (the degree of assertiveness in the exchange). The textual domain involves the thematic structure of the text. The second is analysis of discourse practice, through which texts are produced and received; this dimension involves analysis of the process of production, interpretation, distribution, and consumption. It is concerned with how people interpret and reproduce or transform texts. The third dimension is analysis of social practices, focusing in particular on the relation of discourse to power and ideology; this practice, is concerned with issues of power - power being a construct that is realized through inter-discursivity and hegemony. Analysis of this dimension includes exploration of the ways in which discourses operate in various domains of society. Of course, both van Dijk's and Fairclough's versions of CDA focus on media text and context (Kuo \& Nakamura, 2005, p. 398; Rogers et al., 2005 , p. 371).

\section{METHODOLOGY}

In the present study, two sets of data were examined in order of priority and importance in journalism: headlines and lead paragraphs. The choice of the headlines for a close examination is motivated by the fact that the headlines serve to define the topic of a text, and what appears in the headline is usually considered the most pertinent and important information in the text (Bowles \& Borden, 1997 as cited in Wang, 2009, p. 756). Turning to the reasons why lead paragraphs were selected, it should be noted that a summary lead is the "first sentence(s) in a straight news story which serves to summarize the news event and by principle, it is to be written to include only the most important facts of the story" (Lee, 2006, p. 317-318). Hence, if this part of the news story bears a kind of ideological bias, it will suffice to meet the objectives of the present study. Accordingly, the analysis of full texts was overlooked to prevent a sense of redundancy in the task.

To fulfill the task, some news excerpts of western newspapers -from UK and US - were selected as the samples for analysis. The samples were aggregated from a time period of 25 January through 25 August 2012. Among the newspapers published in the US and UK, ten of the most popular and highly referred ones were selected including Independent, the Daily Mirror, the Guardian, the Daily Telegraph, the Daily Mail from the UK; and the New York Times, the Los Angeles Times, the USA Today, the Washington Post, the Wall Street Journal from the US. 
The procedure for analyzing data included the citation of ten headlines for each ideologically-conflicting topic. These headlines were examined one by one followed by a brief description. Then, the related lead paragraphs followed the headlines of the topic along with their descriptions and analyses. These paragraphs were analyzed from three perspectives: lexicalization and collocational patterns, ideological square, and intertextual framing. After applying suitable linguistics tools for each case, the study turned to the other topics. Similarly, this cycle was repeated for the other two topics too. Finally, the results were gathered and presented.

\section{DATA ANALYSIS AND DiscusSION}

The news excerpts chosen to be analyzed in this chapter were categorized based on their topics. This classification respectively included: Iran Nuclear Program, Iran Sanctions, and Syria Crisis. All these topics are ideologically controversial since Iran's viewpoints for them are completely different from those of the western counterparts.

\section{A. Iran Nuclear Program: Headline Analysis}

\begin{tabular}{l}
\hline (Daily Mail, 01 August 2012) \\
\hline $\begin{array}{l}\text { Defense Secretary Leon Panetta threatens Iran with military strike if it develops nuclear weapons, but Israel says the } \\
\text { promises of force aren't enough }\end{array}$ \\
\hline
\end{tabular}

The headline issues threat of a possible attack on Iran if the country continues its nuclear weapons program. It is a threatening sentence which implies that its agents - Defense Secretary Leon Panetta and Israel - have the power, authority, ability as well as legitimacy to strike Iran if the country tries to develop nuclear weapons. As it is clear this headline is overwhelmingly biased and full of presuppositions, since when the reader comes across this headline s/he takes for granted that Iran is developing nuclear weapons or at least trying to do so - because the headline is accusing the country of these efforts; Iran is responsible for any possible strike which may happen for it is Iran which is developing nuclear arms; Defense Secretary Leon Panetta and Israel are strong entities that can take practical measurements against Iran if needed - through the use of an active voice which makes the subjects seem powerful; and finally, there must be heavier pressure on Iran and even some practical actions should be devised to stop the country from developing nuclear munitions - because mere promises of force are not sufficient to reach the desired aim. Moreover, the way of titling Leon Panetta as the Defense Secretary injects a degree of formality and seriousness to the threat made by him. It implies that a formal official with authority and liability is menacing Iran of a probable military strike and not a layman, a journalist or commentator, for example.

Looking through a syntactical lens, the use of if clause - if it develops nuclear weapons - puts the responsibility and causality of the action, namely a military strike, on Iran; because we know that if clause is a subordinate clause which happens only if its main clause takes place. Hence, a military strike on Iran happens only if the country develops a nuclear bomb program. In this manner, not only the headline threatens Iran, but also it tries to tacitly express that the rationale for a possible attack lies with the decision Iran makes.

Turning to the analysis of lexical elements of the headline, the choice of the verb develop bears a verbal presupposition too. Since develop means "cause to grow larger, become more powerful from being small or weak", so it is presupposed that Iran has already got nuclear weapons which the country is trying to make them grow larger this time (Oxford, 1975, p. 78). Everybody familiar with Iran's nuclear program knows that the country has never been cited as a state with nuclear arms by International Atomic Energy Agency (IAEA) - though there have been some informal accusations. Therefore the headline could choose the verb start, which suggests a beginning to something and not making it progress, in order to presuppose the mentioned fact. The last notification related to this headline can be seen in the case of the nominalized verb promise. The nominalization used here tries to cover over some aspect of the process that is embarrassing or ideologically uncomfortable, i.e. it implies that instead of making a promise a practical measure should be taken, for instance an attack on Iran.

\section{Iran Nuclear Program: Analysis of Lead Paragraphs Wearing the Lens of Lexical and Collocational Patterns}

Because of the prime importance lexicalization has in CDA studies, and since lexical analysis is one of the most useful tools to understand whether a news story is ideologically biased or not, this linguistic tool was chosen as the first lens of analysis for lead paragraphs. Here is a list of words or collocational patterns which carry ideological traces in their reports for Iran's nuclear program: 
TABLE 1.

IDEOLOGY-LADEN LEXIS AND COLLOCATIONAL PATTERNS USED IN LEADS TO REPRESENT IRAN'S NUCLEAR PROGRAM

\begin{tabular}{|c|c|c|}
\hline & Newspaper & Lexical Choices and Collocational Patterns \\
\hline 1 & DML & Raised the threat of a military strike; if the nation develops nuclear weapons; to reassure a jittery Israel. \\
\hline 2 & DMR & $\begin{array}{l}\text { Military action against the rogue Middle East state; if it continued with its illegal nuclear weapons } \\
\text { programme. }\end{array}$ \\
\hline 3 & DT & $\begin{array}{l}\text { MI6 agents have foiled; Iran's attempts to obtain nuclear weapons; will succeed in arming itself; Secret } \\
\text { Intelligence Service has warned. }\end{array}$ \\
\hline 4 & GU & $\begin{array}{l}\text { The last chance for a diplomatic solution to the gathering crisis; will rob diplomacy; its remaining } \\
\text { credibility and substantially; chance of a devastating conflict. }\end{array}$ \\
\hline 5 & IN & $\begin{array}{l}\text { Major powers to speed up efforts to stop Iran's nuclear programme; cautioning that it would be tougher to } \\
\text { confront the issue; an atomic threshold. }\end{array}$ \\
\hline 6 & LAT & Six world powers; Tehran's disputed nuclear program. \\
\hline 7 & NYT & $\begin{array}{l}\text { Israel warning; it may mount a military strike against Iran; he would press for more time; a campaign of } \\
\text { economic sanctions to work on Tehran. }\end{array}$ \\
\hline 8 & UT & Israel views the threat posed by a nuclear-armed Iran; greater urgency than the rest of the world. \\
\hline 9 & WP & $\begin{array}{l}\text { To convince Israeli Prime Minister; allow Iran to develop a nuclear weapon; persuading the Israelis to } \\
\text { hold off on unilateral military action. }\end{array}$ \\
\hline 10 & WSJ & $\begin{array}{l}\text { Iranian nuclear program continues to advance; pressure by the United States and its international } \\
\text { partners; inspectors prevented from accessing sites and scientists; Key components of Iran's nuclear } \\
\text { program are being dispersed and moved underground. }\end{array}$ \\
\hline
\end{tabular}

As it is obvious, the italicized words or collocations in the above list imply an ideological understanding in their news reportage. These words or collocations have been subtly applied to represent a negative image of Iran's nuclear program in a way that the readers come to understand that Iran's nuclear program is not a peace-seeking phenomenon; instead it is an attempt to make nuclear bomb and mass destruction weapons. Moreover, in many cases the readers are left with the implication that Iran is challenging the world and peace process in the Middle East because of its suspicious cling to nuclear-related affairs.

\section{Iran Nuclear Program: Analysis of Lead Paragraphs Wearing the Lens of Ideological Square}

There is a clear differentiation between the represented images of "in-group" and "out-group" countries or organizations in the lead paragraphs of the mentioned news stories. Van Dijk's (1998) concept of "ideological square" helps to understand how Iran or Iranians (Others) are degraded as opposed to appreciation of the westerners (We) in the lead paragraphs. The results are as follows:

TABLE 2.

IDEOLOGICAL SQUARE USED IN LEADS TO REPRESENT IRAN'S NUCLEAR PROGRAM

\begin{tabular}{|l|l|l|l|}
\hline & Newspaper & Iran/Iranians & UN/IAEA/Western Officials \\
\hline 1 & DML & Seeking nuclear weapons; punished. & $\begin{array}{l}\text { Powerful; punisher; legitimate; rejecting nuclear } \\
\text { weapons. }\end{array}$ \\
\hline 2 & DMR & $\begin{array}{l}\text { Violator of international laws; having nuclear } \\
\text { weapons program; defiant; convicted. }\end{array}$ & $\begin{array}{l}\text { Strong; punisher; authoritative; rejecting nuclear } \\
\text { weapons. }\end{array}$ \\
\hline 3 & DT & $\begin{array}{l}\text { Dangerous; seeking nuclear weapons; ill- } \\
\text { intended. }\end{array}$ & Cautious; careful; prosperous; advisor. \\
\hline 4 & GU & $\begin{array}{l}\text { Trouble-maker; having disputed nuclear } \\
\text { program. }\end{array}$ & Diplomacy seeking; legitimate. \\
\hline 5 & IN & $\begin{array}{l}\text { Dangerous; seeking nuclear arms; inferior; } \\
\text { violator. }\end{array}$ & Powerful; cautious; superior; legitimate; united. \\
\hline 6 & LAT & Suspicious; cause of concern. & $\begin{array}{l}\text { Lunished; defiant. } \\
\text { thoughtful. }\end{array}$ \\
\hline 7 & NYT & $\begin{array}{l}\text { Dangerous; nuclear-armed; threatening; } \\
\text { militaristic. }\end{array}$ & $\begin{array}{l}\text { Careful; wise. } \\
\text { Cause of concern; seeking nuclear weapons; }\end{array}$ \\
\hline 8 & UT & $\begin{array}{l}\text { Punished; suspicious; fraudulent; inferior; } \\
\text { potentially dangerous. }\end{array}$ & $\begin{array}{l}\text { Superior; authoritative; legitimate. } \\
\text { superior. }\end{array}$ \\
\hline 9 & WP & WSJ &
\end{tabular}

As it is observed, the image of Iran or Iranian nuclear programs (Others) has been depicted in a negative manner through the implication of such meanings as: seeking nuclear weapons, punished figure, violator of international laws, having nuclear weapons program, defiant, convicted, dangerous, ill-intended, trouble-maker, having disputed nuclear program, inferior, suspicious, cause of concern, threatening, militaristic, fraudulent, and potentially dangerous. Western officials and their allies (We), in contrast, have been stereotyped as powerful, punisher, legitimate, rejecting nuclear weapons, authoritative, cautious, careful, prosperous, advisor, diplomacy seeker, superior, united, constituting a united front, rational, thoughtful, and wise.

\section{Iran Nuclear Program: Intertextual Analysis of Lead Paragraphs}

Intertextual analysis is another tool to extract ideological traces placed in the news texts. The following table itemizes the voices projected in the lead paragraphs to represent Iran's nuclear program. It clarifies the news actors and participants who have their says in the lead paragraphs while at the same time trying to show whose voices have been 
silenced (reporting the ideas of one side and ignoring those of the other side) or muted (when no voice from both sides is echoed) in the texts.

TABLE 3.

NEWS ACTORS AND PARTICIPANTS QUOTED IN THE LEADS TO REPRESENT IRAN'S NUCLEAR PROGRAM

\begin{tabular}{|l|l|l|l|}
\hline & Newspaper & Voice of Iran/Iranian Officials & Voice of UN/IAEA/Western Officials \\
\hline 1 & DML & Silenced & Defense Secretary Leon Panetta \\
\hline 2 & DMR & Silenced & The PM of Britain \\
\hline 3 & DT & Silenced & $\begin{array}{l}\text { MI6 agents; the head of the Secret Intelligence } \\
\text { Service }\end{array}$ \\
\hline 4 & GU & No voice & No voice \\
\hline 5 & IN & Silenced & Ehud Barak, the Defence Minister of Israel \\
\hline 6 & LAT & Iran & Six world powers \\
\hline 7 & NYT & Silenced & Israel; President Obama \\
\hline 8 & UT & Silenced & Israel; Israel's defense minister \\
\hline 9 & WP & Silenced & President Obama; U.S. officials \\
\hline 10 & WSJ & Silenced & $\begin{array}{l}\text { International Atomic Energy Agency (IAEA); agency } \\
\text { inspectors }\end{array}$ \\
\hline
\end{tabular}

The news actors and speakers in the analyzed newspapers can be divided into two general categories: Iran or Iranian officials speaking about their nuclear program; and Western officials - and their allies - and international organizations like $U N$ and IAEA expressing their ideas on Iran's nuclear program. As the table shows, the second group has got a considerable priority for the journalists and newspapers in the news reportage of Iran's nuclear program, that is, when the newspapers are reporting Iran's nuclear program they are largely concerned to project the words and claims of the western officials and not those of the Iranian ones. One of the results of such an intertextual framing is that Iran and Iranian officials can not express their ideas or claims on the issues which are challenged by the western front. Consequently, the readers are deprived from hearing what Iran believes about the accusations, claims, ideas, and condemnations made by westerners. In this way, they take for granted that what the westerners say or claim is the immaculate truth and Iran deserves such negative actions or measurements.

\section{B. Iran Sanctions: Headline Analysis}

The second topic which is ideologically controversial between Iran and western countries deals with the sanctions imposed upon Iran by United Nations and the US. Following the Islamic revolution of 1978 in Iran a series of sanctions started to be imposed on the country both by United Nations and the US. These sanctions were expanded little by little and in the recent years they covered such vital areas as banking systems, shipping and navigation tools, and finally oil industry. While Iranian government identifies these sanctions as illegal and ineffective, many western countries believe that such sanctions are preliminary and effective steps to be taken so as to limit Iran's power and authority.

(Daily Mirror, 24 January 2012)

Iran urged to "come to its senses" and drop its nuclear programme as the EU imposes an oil embargo

The headline implies that Iran will behave wisely and stop its nuclear program when European Union (EU) starts to levy an oil embargo on the country's oil industry. Lexically analyzing and in presupposition terms, the choice of the verb urge - to make a person or an animal [etc.] move more quickly and in a particular direction, especially by pushing or forcing them - not only degrades Iran's position and prestige to animals and irrational entities, but also it takes for granted that the country can be convinced to behave in the right manner just and just through the use of force - and not conversation (Oxford, 2005, p. 1688). Besides, the marked phrase come to its senses presupposes that the country has not been behaving rationally, and that it has been following an illogical manner up to now. In the same vein, the verb drop meaning "to not continue with something" also presupposes that Iran has got an ongoing nuclear program (Oxford, 2005, p. 470).

Wearing the lens of transitivity analysis, we might ask such questions as: who punishes whom? Who is the superior? Or who is the inferior? The answers to these questions are EU punishes Iran with oil embargo, EU, and Iran, respectively. Thus, as it is seen in all the cases it is Iran which has the negative attributions while on the other hand EU - or as ideological square suggests in-group we- owns all the positive and strong stances.

1. Iran Sanctions: Analysis of Lead Paragraphs Wearing the Lens of Lexical and Collocational Patterns

The analysis of lexical items and collocational patterns used in lead paragraphs to depict Iran sanctions was interesting too. The results are as follows: 
TABLE 4.

IDEOLOGY-LADEN LEXIS AND COLLOCATIONAL PATTERNS USED IN LEADS TO REPRESENT IRAN SANCTIONS

\begin{tabular}{|c|c|c|}
\hline & Newspaper & Lexical Choices and Collocational Patterns \\
\hline 1 & DML & $\begin{array}{l}\text { Tensions with Iran have ratcheted up several notches; the onset of severe new EU and US sanctions; } \\
\text { came into force on } 1 \text { st July. }\end{array}$ \\
\hline 2 & DMR & Iran has stepped up threats; the $\boldsymbol{E} \boldsymbol{U}$ agreed an oil embargo against the country. \\
\hline 3 & DT & $\begin{array}{l}\text { Iranians are abandoning traditional eating habits; being thrown out of work at alarming rates; } \\
\text { running short of medicines as the nation braces itself for fresh sanctions; forcing its leaders to scrap } \\
\text { their suspect nuclear programme. }\end{array}$ \\
\hline 4 & GU & $\begin{array}{l}\text { Ehud Barak has warned that tougher sanctions need to be imposed; the unprecedented oil embargo } \\
\text { agreed by the European Union earlier this week. }\end{array}$ \\
\hline 5 & IN & $\begin{array}{l}\text { The toughest sanctions; unveiled by the European Union; the last chance to resolve the nuclear } \\
\text { stand-off before military strikes are considered. }\end{array}$ \\
\hline 6 & LAT & $\begin{array}{l}\text { Oil embargo took effect; a defiant Iran; a new round of war games; firing missiles at models of } \\
\text { foreign air bases. }\end{array}$ \\
\hline 7 & NYT & $\begin{array}{l}\text { Attempting to halt Iran's nuclear program with diplomacy, sanctions and sabotage; sweeping new } \\
\text { sanctions; to cut the country off from the global oil market; the best hope for forcing Iran to change its } \\
\text { course. }\end{array}$ \\
\hline 8 & UT & $\begin{array}{l}\text { International sanctions; to pressure its leaders; to abandon its nuclear aspirations; sanctions are } \\
\text { hurting the Iranian people. }\end{array}$ \\
\hline 9 & WP & $\begin{array}{l}\text { Near-constant talk about war with Iran; one counterintuitive possibility; to deter an Israeli strike; a } \\
\text { pressure campaign; if pursued vigorously; eventually lead to regime change in Iran. }\end{array}$ \\
\hline 10 & WSJ & $\begin{array}{l}\text { Iranian regime races to fulfill its nuclear ambitions; the world faces a stark choice; the risk of a } \\
\text { military conflict with Iran; a nuclear arms race in the already-volatile Middle East; if like-minded } \\
\text { nations act immediately, to deliver a potentially decisive economic blow to the regime. }\end{array}$ \\
\hline
\end{tabular}

The italicized words or collocations in the above list imply an ideological understanding in their news reportage. They have been subtly applied to represent a negative image of Iran and legitimize the sanction imposition by western countries. Through an elaborate way of word choice, these collocations try to misrepresent Iran's image and imply that Iran is a defiant country which endangers world peace by its stubborn and invoking activities. In this manner, the readers come to understand that sanction imposition on Iran is a legal measurement which limits the country and makes it obey the rules of western countries. Therefore, the readers have got no choice except to support the western imposition of sanctions on Iran.

\section{Iran Sanctions: Analysis of Lead Paragraphs Wearing the Lens of Ideological Square}

The analysis of ideological square created in the lead paragraphs of the news stories on Iran sanctions indicates that there is a high proclivity to represent westerners as superior to Iranians. This superiority paves the ground for the process of legitimating sanction imposition on the country. The following table elaborates on how Iran or Iranians (Others) are differentiated from westerners (We) in the lead paragraphs of the newspapers manifesting the news of Iran sanctions:

TABLE 5.

IDEOLOGICAL SQUARE USED IN THE LEADS TO REPRESENT IRAN SANCTIONS

\begin{tabular}{|l|l|l|l|}
\hline \multicolumn{2}{|c|}{ IDEOLOGICAL SQUARE USED IN THE LEADS TO REPRESENT IRAN SANCTIONS } \\
\hline 1 & Newspaper & Iran/Iranians & UN/IAEA/Western Officials \\
\hline 2 & DML & Inferior; trouble-maker; punished severely. & Authoritative; limiter; punisher; legitimate. \\
\hline 3 & DT & Irrational; defiant; resistant; invoking. & Punisher; authoritative. \\
\hline 4 & GU & $\begin{array}{l}\text { Under pressure; punished; weak; poor; } \\
\text { seeking nuclear weapons; suspected. }\end{array}$ & $\begin{array}{l}\text { Punisher; } \\
\text { authoritative; successful. }\end{array}$ \\
\hline 5 & IN & Punished; defiant; inferior. & $\begin{array}{l}\text { Punisher; authoritative; cautious; superior; } \\
\text { legitimate. }\end{array}$ \\
\hline 6 & LAT & Inferior; causing problem. & $\begin{array}{l}\text { Advisor; problem shooter; superior; legitimate; } \\
\text { united; powerful. }\end{array}$ \\
\hline 7 & NYT & $\begin{array}{l}\text { Defiant; militaristic; invoking; threatening } \\
\text { peace. }\end{array}$ & Punisher. \\
\hline 8 & UT & Punished; defiant; stubborn. & $\begin{array}{l}\text { Powerful; superior; legitimate punisher; tactful; } \\
\text { rational. }\end{array}$ \\
\hline 9 & WP & Punished; inferior; fraudulent; ambitious. & Superior; punisher; authoritative; legitimate. \\
\hline 10 & WSJ & Under pressure; punished; weak. & $\begin{array}{l}\text { Thoughtful; rational; authoritative; punisher; } \\
\text { powerful. }\end{array}$ \\
\hline
\end{tabular}

As it is observed, the image of Iran or Iranian nuclear programs (Others) has been depicted in a negative frame through the implication of such meanings as: Inferior, trouble-maker, punished severely, Irrational, defiant, resistant, invoking, Under pressure, weak, poor, seeking nuclear weapons, suspected, militaristic, threatening peace, stubborn, fraudulent, ambitious, economically weak, and potentially dangerous. Western officials and their allies (We), in contrast, have been stereotyped as: superior, authoritative, limiter, punisher, legitimate, successful, cautious, advisor, problem shooter, united, powerful, tactful, rational, and thoughtful.

3. Iran Sanctions: Intertextual Analysis of Lead Paragraphs 
The analysis of news actors and participants appeared in the lead paragraphs of the news stories reporting on Iran sanctions shows that there is no balance in reporting the voices of the western and Iranian officials speaking about Iran sanctions, i.e. the voices of westerners are projected more frequently than those of the Iranian officials. The following table shows whose voices have been silenced (reporting the ideas of one side and ignoring those of the other side) or muted (when no voice from both sides is echoed) in the lead paragraphs of the news stories reporting on Iran sanctions:

TABLE 6.

NEWS ACTORS AND PARTICIPANTS QUOTED IN THE LEADS TO REPRESENT IRAN SANCTIONS

\begin{tabular}{|l|l|l|l|}
\hline & Newspaper & Voice of Iran/Iranian Officials & Voice of UN/IAEA/EU/Western Officials \\
\hline 1 & DML & No voice & No voice \\
\hline 2 & DMR & Iran & No voice \\
\hline 3 & DT & Silenced & No voice \\
\hline 4 & GU & Silenced & Israel's defence minister, Ehud Barak \\
\hline 5 & IN & Silenced & European Union \\
\hline 6 & LAT & Iran & No voice \\
\hline 7 & NYT & Silenced & Obama administration; American allies; experts \\
\hline 8 & UT & Silenced & Iran analysts \\
\hline 9 & WP & Silenced & Obama administration \\
\hline 10 & WSJ & Silenced & No voice \\
\hline
\end{tabular}

The news actors of the news stories reporting on Iran sanctions can be divided into two general categories: Iran or Iranian officials speaking about their beliefs on the case; and Western officials - and their allies - and international organizations like $E U$ and $U N$. As the table shows, the second group has got the upper voice in the news reportage of Iran sanctions, that is, when the newspapers are reporting Iran sanctions they are largely concerned to project the words and claims of the western officials and not those of the Iranian ones. The fact that the voices of western officials have been projected more often ( 7 to 2 ) supports this claim. One of the results of such an intertextual framing is that Iran and Iranian officials can not express their ideas about the sanctions imposed on the country by westerners. Consequently, the readers are deprived from hearing a balanced and unbiased report and so more susceptible to go along with the westerners in levying harsher sanctions on Iran.

\section{Syria Crisis: Headline Analysis}

The third and last topic to be analyzed in this study is concerned with the Syrian Crisis which started in 2011. After a series of uprisings and revolutions in Arab world and countries like Tunisia, Libya, Egypt and Bahrain - labeled as Islamic Awakening by Iran and Arab Spring by western countries - this wave reached Syria and the country entered a critical period of riot, street battle and protest. While western countries started to condemn the government of brutal crackdown and an autocratic system of ruling, Iran along with Syria claimed that what is happening inside Syria is not the real desire of the people living there but a series of hooliganism and terrorist acts mainly set up and supported by western countries and their allies to topple the Syrian government and replace it by a secular system. Ignoring which side is correct - for it is not in the domain of the present study - the researcher made an effort to focus on the western manifestations of the case so as to extract those news stories which he found biased in their interpretations and manifestations.

\begin{tabular}{|l|}
\hline (The Washington Post, 13 July 2012) \\
\hline Clinton condemns massacre in Syrian village, accuses government of murder \\
\hline
\end{tabular}

The headline reports Clinton's condemnation of the massacre in Syrian village as well as her accusation of the government of murder. It posits 'Clinton' as the subject or in transitivity terms Senser of the mental processes 'condemn' and 'accuse'. 'Massacre' and 'government' are the Phenomena of these two processes, respectively. Hence, it is Clinton who is active and can project her voice, whereas Syrian government is passive and has got no voice to echo in the headline. Similar to the previous headline once again it is observed that a negative image of Syria has been depicted through representing the country as: passive object, guilty and brutal, cruel, criminal, and oppressive.

In lexical terms, the choice of the noun massacre meaning "the killing of a large number of people especially in a cruel way" further implies that Syrian government is an aggressive and cruel regime which doesn't care about such vital laws as human rights and democracy (Oxford, 2005, p. 943). In addition, the active voice of Clinton also helps to presuppose that this massacre has really happened and there is no doubt about it, because 'condemn' and 'accuse' are the results of a crime or an illegal action, and can not be expressed if there is not any evil thing.

\section{Syria Crisis: Analysis of Lead Paragraphs Wearing the Lens of Lexical and Collocational Patterns}

Here are the results of this kind of analysis which was done for the lead paragraphs scrutinized: 
TABLE 7.

WORDS AND COLLOCATIONS USED IN THE LEADS TO REPRESENT SYRIA CRISIS

\begin{tabular}{|c|c|c|}
\hline & Newspaper & Lexical Choices and Collocational Patterns \\
\hline 1 & DML & $\begin{array}{l}\text { The lifeless corpse of four-month-old Afaf Mahmmod Al-Sarakb lies limp and motionless; tortured to } \\
\text { death by government security officers; parents were arrested. }\end{array}$ \\
\hline 2 & DMR & Top generals fled; Syrian tyrant Bashar al-Assad; to unleash chemical weapons. \\
\hline 3 & DT & A possible strike at Syria's chemical weapons stockpile ; is thought to be the largest in the world. \\
\hline 4 & GU & $\begin{array}{l}\text { To stop the violence; the regime of Bashar al-Assad to be violently removed; fleeing to Qatar; only } \\
\text { force could remove the Syrian dictator; denounced the embattled regime. }\end{array}$ \\
\hline 5 & IN & $\begin{array}{l}\text { Damascus bombing killed or severely injured; Bashar al-Assad's inner circle; responsible for directing } \\
\text { the bloody crackdown; the uprising. }\end{array}$ \\
\hline 6 & LAT & $\begin{array}{l}\text { The Holocaust; the genocide; to stop the killing; violence unfolds in Syria; ineffectual statements of } \\
\text { condemnation. }\end{array}$ \\
\hline 7 & NYT & $\begin{array}{l}\text { Growing conviction; Assad family's 42-year grip on power in Syria; collapse of the Syrian } \\
\text { government; chemical weapons Syria is thought to possess; use on opposition forces and civilians. }\end{array}$ \\
\hline 8 & UT & $\begin{array}{l}\text { Western nations expelled Syrian diplomats; the regime of Bashar Assad; only military force can stop } \\
\text { the massacre of women and children. }\end{array}$ \\
\hline 9 & WP & $\begin{array}{l}\text { A massacre of about } 200 \text { people; international condemnation, accusing the government of having } \\
\text { "murdered" civilians. }\end{array}$ \\
\hline 10 & WSJ & Extended its sanctions; confirmed a full Iran oil embargo; to go into effect. \\
\hline
\end{tabular}

The italicized words or collocations in the above list imply an ideological understanding in their news reportage. These words or collocations have been skillfully applied to represent a negative image of Syria and misrepresent the situation inside the country. In this manner, the readers come to understand that Syrian government is a cruel and savage body which violates human rights and kills its civilians. Meanwhile, it is also implied that the westerners are fighting against the brutality and inhuman measurements of Syrian government.

\section{Syria Crisis: Analysis of Lead Paragraphs Wearing the Lens of Ideological Square}

An "in-group" and "out-group" differentiation between Iran/Syria officials and UN/EU/Western officials is clear in the lead paragraphs of newspapers reporting on Syria crisis. Van Dijk's concept of "ideological square" helps to understand how the first group (Others) is misrepresented as opposed to appreciation of the second group (We). The results are as follows:

TABLE 8.

IDEOLOGICAL SQUARE USED IN THE LEADS TO REPRESENT SYRIA CRISIS

\begin{tabular}{|c|c|c|c|}
\hline & Newspaper & Syria/Iran & UN/EU/Western Officials \\
\hline 1 & DML & $\begin{array}{l}\text { Criminal; savage; murderer; inhuman; } \\
\text { oppressive; violating human rights. }\end{array}$ & $\begin{array}{l}\text { Defending human rights; caring about civilians' } \\
\text { lives; sympathetic. }\end{array}$ \\
\hline 2 & DMR & $\begin{array}{l}\text { Cruel; criminal; dictator; violating human } \\
\text { rights. }\end{array}$ & $\begin{array}{l}\text { Supporting democracy; thoughtful; caring about } \\
\text { human rights }\end{array}$ \\
\hline 3 & DT & $\begin{array}{l}\text { Having chemical weapons stockpile; potentially } \\
\text { dangerous; threatening. }\end{array}$ & Powerful; legitimate; authoritative; advisor. \\
\hline 4 & GU & Dictator; cruel; irrational; violent. & Peace-seeking; powerful. \\
\hline 5 & IN & $\begin{array}{l}\text { Murderer; cause of massacre; responsible for } \\
\text { lost lives. }\end{array}$ & $\begin{array}{l}\text { Defending human rights; caring about civilians' } \\
\text { lives. }\end{array}$ \\
\hline 6 & LAT & $\begin{array}{l}\text { Violent; committing Holocaust-like crimes; } \\
\text { killer; condemned. }\end{array}$ & $\begin{array}{l}\text { Powerful; legitimate; authoritative; constituting a } \\
\text { united front. }\end{array}$ \\
\hline 7 & NYT & $\begin{array}{l}\text { Non-democratic; inhuman; having chemical } \\
\text { weapons; potentially dangerous; threatening. }\end{array}$ & $\begin{array}{l}\text { Authoritative; advisor thoughtful; defending human } \\
\text { rights; caring about civilians' lives. }\end{array}$ \\
\hline 8 & UT & Criminal; violent; savage; murderer. & $\begin{array}{l}\text { Legitimate; authoritative; advisor; thoughtful; } \\
\text { defending human rights; caring about civilians' } \\
\text { lives. }\end{array}$ \\
\hline 9 & WP & Condemned; savage; murderer; inhuman. & $\begin{array}{l}\text { Defending human rights; caring about civilians' } \\
\text { lives; superior. }\end{array}$ \\
\hline 10 & WSJ & Punished; inferior; loser. & Legitimate; punisher; superior. \\
\hline
\end{tabular}

As it is observed, the image of Syria and Iran (Others) has been depicted in a negative manner through the application of such meanings and concepts as: criminal, savage, murderer, inhuman, oppressive, violating human rights, cruel, dictator, having chemical weapons stockpile, potentially dangerous, threatening, irrational, violent, murderer, cause of massacre, responsible for lost lives, committing Holocaust-like crimes, killer, condemned, non-democratic, inhuman, potentially dangerous, punished, inferior, and loser. Western officials and their allies (We), in contrast, have been stereotyped as: defending human rights, caring about civilians' lives, sympathetic, supporting democracy, thoughtful, powerful, legitimate, authoritative, advisor, peace-seeking, constituting a united front, superior, and punisher.

\section{Syria Crisis: Intertextual Analysis of Lead Paragraphs}

The last table identifies the voices projected in the lead paragraphs to represent Syria crisis. It clarifies the news actors and participants who appear in the lead paragraphs while at the same time trying to show whose voices have been silenced or muted in the texts. 
TABLE 9.

NEWS ACTORS AND PARTICIPANTS QUOTED IN THE LEADS TO REPRESENT SYRIA CRISIS

\begin{tabular}{|l|l|l|l|}
\hline & Newspaper & Voice of Syria /Iran Officials & Voice of UN/EU/Western Officials \\
\hline 1 & DML & Silenced & No voice \\
\hline 2 & DMR & Silenced & Three fled top generals of Syria \\
\hline 3 & DT & Silenced & Washington government \\
\hline 4 & GU & Silenced & $\begin{array}{l}\text { Syria's former envoy to Iraq; the ambassador, Nawaf } \\
\text { al-Fares (2) }\end{array}$ \\
\hline 5 & IN & Silenced & No voice \\
\hline 6 & LAT & Silenced & The world community; the U.S. and its allies \\
\hline 7 & NYT & Silenced & Obama administration officials \\
\hline 8 & UT & Silenced & Western nations; anti-Bashar Al-Assad rebels \\
\hline 9 & WP & Silenced & Secretary of State Hillary Rodham Clinton \\
\hline 10 & WSJ & No voice & The European Union \\
\hline
\end{tabular}

The news actors and speakers in this part can be divided into two general categories: Syria /Iran Officials, and UN/EU/Western Officials. As the table shows, the voice of the first group has been completely silenced and muted (zero voice) while the voice of westerners has been empowered dramatically (13 voices). One of the results of such an intertextual framing is that Syrian/Iranian officials can not express their ideas and claims on the issues mentioned by the western front. Furthermore, since there is no balance in reporting the news and because of the negative images westerners present on the case, the possibility to convince the readers that Syrian government is an aggressive figure is strongly increased.

\section{CONCLUSION}

In a nutshell, the mass media simply cannot provide a perspective that is totally free from subjective interpretation of events; on the contrary, media institutions "tend to construct reality in a manner congruent with their underlying ideological and political functions" (Kuo \& Nakamura, 2005, p. 411). In short, the study proved that linguistic tools are among the most important items which result in a biased representation of news stories. Moreover, the results showed that: the language of western newspapers - and particularly American and British ones - is highly ideological while representing the news of conflicting ideas between Iran and western countries. Moreover, the study proved that linguistic tools - or the ways of using these tools - have got an incredible discoursal capability to misrepresent news stories. Finally, it was also observed that such ideological representations and biased languages in news media can result in legitimation of one side and suppression of the other side.

\section{REFERENCES}

[1] Askeland, G. A. \& Payne, M. (2006). Social work education's cultural hegemony. International Social Work, 49.6, $731-743$.

[2] Bloor, M. \& Bloor, T. (2007). The Practice of Critical Discourse Analysis. London: Hodder Education.

[3] Das, A. (2009). Political Crisis and Media's Role towards Conflict Resolution: A Study in Indian Context. http://utcc2.utcc.ac.th/localuser/amsar/PDF/Document52/Arjun_Template.pdf. (accessed 8/1/2012).

[4] Demont-Heinrich, C. (2008). American Triumphalism and the "Offensive" Defensiveness of the French: French as a Foil for English in U.S. Prestige Press Coverage of the Global Hegemony of English. Journal of Communication Inquiry, 32.3, 271-291.

[5] Fairclough, N. (1995). Critical Discourse Analysis: The Critical Study of Language. London: Longman.

[6] Gerber, A., Karlan, D. \& Bergan, D. (2007). Does The Media Matter? A Field Experiment Measuring the Effect of Newspapers on Voting Behavior and Political Opinions. Effect of Newspapers on Voting Behavior and Political Opinions. international.ucla.edu/media/files/bergan_gerber_karlan.pdf. (accessed 7/72012).

[7] Hakam, J. (2009). The 'cartoons controversy': a Critical Discourse Analysis of English-language Arab newspaper discourse. Discourse \& Society, 20.1, 33-57.

[8] Joye, S. (2010). News discourses on distant suffering: a Critical Discourse Analysis of the 2003 SARS outbreak. Discourse \& Society, 21.5, 586-601.

[9] Kuo, S. H. \& Nakamura, M. (2005). Translation or transformation? A case study of language and ideology in the Taiwanese press. Discourse \& Society, 16.3, 393-417.

[10] Lee, C.-S. (2006). "Differences in News Translation between Broadcasting and Newspapers: A Case Study of Korean-English Translation". Meta: Translators' Journal, 51, 2. p. 317-327. http://www.erudit.org/apropos/utilisation.html (accessed 5/7/2012).

[11] Li, J. (2009). Intertextuality and national identity: discourse of national conflicts in daily newspapers in the United States and China. Discourse \& Society, 20.1, 85-121.

[12] Oxford Advanced Learner's Dictionary ( $7^{\text {th }}$ Ed.). (2005). Oxford: Oxford University Press.

[13] Oxford Dictionary of Current Idiomatic English (1975). Oxford: Oxford University Press.

[14] Popp, R. K. (2006). Mass Media and the Linguistic Marketplace: Media, Language, and Distinction. Journal of Communication Inquiry, 30.1, 5-20.

[15] Resende, V. D. M. (2009). 'It's not a matter of inhumanity': a critical discourse analysis of an apartment building circular on 'homeless people'. Discourse \& Society, 20.3, 363-379.

[16] Richardson, J. H. (2007). Analysing Newspapers: An Approach from Critical Discourse Analysis. Hampshire: Palgrave Macmillan.

[17] Rogers, R., Malancharuvil-Berkes, E., Mosley, M., Hui, D. \& Joseph, O. G. (2005). Critical Discourse Analysis in Education: A Review of the Literature. Review of Educational Research, 75.3, 365-416. 
[18] Tardy, C. M. (2009). 'Press 1 for English': textual and ideological networks in a newspaper debate on US language policy. Discourse \& Society, 20.2, 265-286.

[19] Van Dijk, T. A. (2001). Multidisciplinary CDA: A plea for diversity. In R. Wodak \& M. Meyer (Eds.), Methods of critical discourse analysis (pp. 95-120). London: Sage.

[20] Van Dijk, T. A. (1988). News as Discourse. New Jersey: Lawrence Erlbaum Associates, Inc.

[21] Vighi, F. \& Feldner, H. (2007). Ideology Critique or Discourse Analysis? : Zizek against Foucault. European Journal of Political Theory, 6.2, 141-159.

[22] Wang, H. C. (2009). Language and ideology: gender stereotypes of female and male artists in Taiwanese tabloids. Discourse \& Society, 20.6, 747-774.

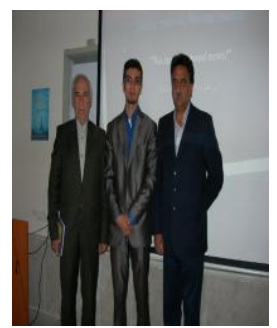

Amir Shojaei was born in Tabriz, Iran on September 5, 1987. He holds an M.A. in Translation Studies from Azad University of Quchan, Iran. He lives in Tabriz and received his B.A. in the field from Azad University of Tabriz, Iran in 2009. Besides teaching various courses of EFL at some English institutes, he does some practical translational affairs from English to Persian and Azeri for a number of newspapers largely including political and journalistic texts. His main areas of interest include Critical Discourse Analysis, Political Discourse, News Analysis and Media Representation. He has got two more papers published in the field.

Kazem Youssefi was born in Mashhad, Iran on September 22, 1952. He holds a PhD in Translation Studies from the University of Sains Malaysia. He is a faculty member at Islamic Azad University of Quchan and has been teaching for over 35 years such different subjects of the field as Literary Translation, Translation Criticism, Translation Workshop, Theories of Translation, Translation Models, Linguistics, Translation of Islamic Texts, Translating Advanced English, and Metaphoric \& Idiomatic Expressions. His main area of interest is Translation of Literary Texts.

Hossein Shams Hosseini holds a PhD in Linguistics and TEFL. He has been a faculty member for seventeen years and Head of MA Department of English Translation at Islamic Azad University, Quchan since 2009. He is the author of two books on journalistic terminology as well as idioms and proverbs. He has seven published articles, two of which have been presented in international conferences abroad. His research interests are Task Based English Teaching, Oral interpretation, Assessment, and Translation studies. 